\title{
Demographics as Variables in Assessing the Study Habits of High School Students in a Catholic School
}

\author{
Judy N. Fernandez ${ }^{1}$ and Celo I. Magallanes ${ }^{2}$ \\ ${ }^{1}$ St. Luke's Academy, Inc., Valderrama, Antique, Philippines \\ ${ }^{2}$ University of Negros Occidental-Recoletos, Bacolod City, Philippines
}

\begin{abstract}
Article history
Submitted: 24 October 2020

Revised: 11 November 2020

Accepted: 12 November 2020
\end{abstract}

\section{Keywords}

Study Habits

Demographics

High School Students

Catholic School

Descriptive-Correlational

Antique
Guidance and Counseling

Introduction. Study habits and skills differ from one person to another. Effective study habits are instrumental for students to gain mastery of a topic learned and ensure good academic performance. Study habits that students employ to cope with their lessons are ways, techniques, and learning styles which may include, but not limited to, time management or the number of hours spent studying their lessons and making assignments; study environment, test-taking skills which include students' readiness or preparedness in taking tests; notetaking skills or student's efficiency in taking down notes during class hours or while reading; reading skills which are the student's ability to understand and comprehend lessons, tests, and reading materials; writing skills or the ability to observe correct grammar and to write effectively; and math skills or the facility and ease in solving math problems. With the advancement of technology, students nowadays engage themselves more in gadgets and spend more time in electronic media and social media; thus, students' study habits are slowly deteriorating when it comes to frequency and quality. Hence, this study was conducted to determine the level of study habits in relation to selected demographics of high school students in a Catholic School in Antique during the school year 2019-2020. Likewise, it measured the relationship between the demographic variables and their extent of study habits and determined which areas predict the students' study habits.

Methods. The study used a descriptive-correlational research design to describe and correlate the study habits of randomly selected 215 high school students of a diocesan Catholic school in Antique. A standardized Study Habits Questionnaire adapted from Virginia Gordon University: A Guidebook and Readings for New Students were used along with a checklist on distractors affecting study habits to collect the data. Mean, Standard Deviation, frequency count, percentage distribution, Spearman rank correlation, and Chi-square test of association were used to analyze the data.

Results. The findings generally showed that junior high school students have already developed a high extent of study habits. When grouped according to demographics, both male and female students have a high extent of study habits. In terms of family structure, students from intact and non-intact families also have high study habits. However, when grouped according to year level, the upper years have a lower extent of study habits than the lower years. In terms of dimensions of study habits, students scored low in test-taking skills and reading skills. However, they scored high in time management, study environment, note-taking, writing skills, and math skills. In addition, there is no significant relationship between study habits and sex as well as between study habits and family structure. However, there is a significant relationship between study habits and grade level and between study habits and location or residence. Moreover, social media, TV programs, and noisy environment were rated as the top three among the ten identified factors affecting students' study habits, and they serve as potential distractors to effective studying.

Conclusion. The junior high school students have adequately developed the study practices and skills required to successfully hurdle the school's challenges. However, their low scores in reading and test-taking skills pose a great challenge to teachers, counselors, and school administrators in providing learning experiences to develop habits and academic skills in these areas. Since adopting and practicing effective study habits depend solely on individual qualities like personality, attitude 
toward learning, self-determination and motivation, and self-efficacy, the students need to cultivate them. The school may provide opportunities to enhance students' potential.

Practical Value of the Paper. The study significantly contributes to the few existing literature on Study Habits. In addition, the findings of the study served as the basis for school administrators, guidance counselors, and teachers in formulating a comprehensive and effective intervention program in realizing the importance of good study habits and developing habits that will work for the Junior high school students to achieve optimal academic performance.

\section{References}

Amin, S. \& Mattoo, M. (2012). Influence of Heavy and Low Television Watching on Study Habits of Secondary School Students-A Study. 3. 10.7176/NMMC.vol321-29.

Aquino, L.B. (2011). Study Habits and Attitudes of Freshmen Students: Implications for Academic Intervention Programs, University Research Pool, University of Saint Louis, Tuguegarao City, Philippines

Ayesha, B. \& Khurshid, F. (2013). The Relationship of Multiple Intelligence and Effective Study Skills with Academic Achievement among University Students. Global Journal of Human Social Science Linguistics and Education, $13(1), 20-32$

Ayodele, C. S. \& Adebiyi, D. R. (2013). Study Habits as Influence of Academic Performance of University Undergraduates in Nigeria. Research Journal in Organizational Psychology \& Educational Studies, 2.3, p 72-75.

Bakhshialiabad, H., Bakhshi, M., Hassanshahi, G. (2015). Students' Perceptions of the Academic Learning Environment in Seven Medical Sciences Courses based on DREEM. Adv Med Educ Pract. 2015; 6:195-203. doi: 10.2147/AMEP.S60570

Bocar, A. \& Tizon, M. (2017). Study Habits and the Perceived Factors that Distract the Concentration of La Salle University Freshmen. SSRN Electronic Journal. 10.2139/ssrn.2979233.

Chand, S. (2013). Study Habits of Secondary School Students in Relation to Type of School and Type of Family. International Journal of Social Science and Interdisciplinary Research, Vol. 2(7)

Charles-Ogan, G. (2015). Gender Influences on Study Habits of Mathematics Students' Achievement. International Journal of Academic Research and Reflection, 3(7), 24-28.

Jamil, F. \& Khalid, R. (2016). Predictors of Academic Achievement in Primary School Students. Pakistan Journal of Psychological Research. 31. 45-61.

Numan, A. \& Hasan, S. S. (2017). Effect of Study Habits on Test Anxiety and Academic Achievement of Undergraduate Students. Journal of Research and Reflections in Education, 11(1), 1-14.

\section{Correspondence:}

Judy N. Fernandez [judynamo.fernandez@gmail.com]

https://orcid.org/0000-0002-2445-714X 